Pregledni znanstveni članek Review scientific paper (1.02) Besedilo prejeto Received: 20. 7. 2020; Sprejeto Accepted: 28. 9. 2020

UDK UDC: 26-14:27-247

DOI: $10.34291 /$ Edinost/76/Budiselic

(C) 2021 Budiselić CC BY 4.0

Ervin Budiselić

\title{
The Importance of the Jewishness of Jesus for Interpreting the Gospels
}

\author{
Pomen Jezusovega judovskega porekla \\ za interpretacijo evangelijev
}

\begin{abstract}
Both in Judaism and Christianity Jesus was to some extent separated or detached from Judaism. However, as Matthias Henze says, in the last 50 years we have been witnessing significant changes in the approach and view of the Jewish world of the Gospels and consequently the New Testament. This positive shift should affect not only our view of the "Jewishness of Jesus« but also of biblical interpretation. Namely, we can expect that Jesus lived, thought, spoke and taught as a Jew and not as a "Christian" in the historical sense of the word. In terms of biblical interpretation, that means that the proper context for interpreting the Bible is the context of the biblical writers. Accordingly, our goal should be studying historical, cultural or literary contexts in order to discover a worldview context of the biblical authors and with these "glasses" approach to reading the Scriptures.

Based on this reasoning, in the first part of the paper, we will address certain theological and historical reasons for the exclusion of the Jewishness of Jesus from both Judaism and Christianity. In the second part, we will discuss the importance of the Jewishness of Jesus for understanding the worldview context of the biblical authors. In the last part, as a case study, we will demonstrate through the interpretation of Matthew 16,13-20 (the issue of sthe rock «) and Luke 11,1-4 (the Lord's Prayer) through "Jewish eyes" that we can gain a different and even better interpretation of these two texts that better fit the context of the biblical writers.
\end{abstract}

Key words: Jewishness of Jesus, context, worldview, hermeneutics, "the rock", the "Lord's Prayer"

Izvleček: Tako v judovstvu kot v krščanstvu je bil Jezus do neke mere ločen od judovstva. Vendar smo, kot pravi Matthias Henze, $v$ zadnjih 50 letih priča pomembnim spremembam $v$ pristopu in pogledu na judovski svet evangelijev in posledično na Novo zavezo. Ta pozitivni premik naj bi vplival ne samo na naš pogled na "Jezusovo židovstvo", temveč tudi na razlago Svetega pisma. Sklepamo lahko namreč, da je Jezus živel, mislil, govoril in učil kot jud, in ne kot »kristjan " $v$ zgodovinskem pomenu besede. Kar zadeva Sveto pismo, pa to pomeni, da je pravi kontekst za razlago tega kontekst svetopisemskih piscev. V skladu s tem bi moral biti naš cilj preučevanje zgodovinskega, kulturnega ali literarnega konteksta, da bi odkrili svetovnonazorski kontekst svetopisemskih avtorjev in s to perspektivo pristopili k branju Svetega pisma.

Na podlagi tega razmišljanja bomo v prvem delu prispevka obravnavali nekatere teološke in zgodovinske razloge za izključitev Jezusove judovske pripadnosti tako iz judovstva kot 
iz krščanstva. V drugem delu bomo razpravljali o pomenu Jezusovega judovstva za razumevanje svetovnonazorskega konteksta svetopisemskih avtorjev. Vzadnjem delu bomo s študijo primera na podlagi interpretacije Mt 16,13-20 (vprašanje "skale") in Lk 11,1-4 (Gospodova molitev) skozi ijudovske oči pokazali«, da lahko dobimo drugačno in še boljšo interpretacijo teh dveh besedil, ki se bolje prilegata kontekstu svetopisemskih piscev.

Ključne besede:Jezusovo judovstvo, kontekst, hermenevtika, "skala", Gospodova molitev

\section{Introduction}

Both in Judaism and Christianity, for various reasons, Jesus was to some extent separated or detached from Judaism. However, as Matthias Henze $(2018,15)$ says, in the last 50 years we have been witnessing significant changes in the approach and view of the Jewish world of the Gospels and consequently the New Testament. This positive shift should affect not only our view of the »Jewishness of Jesus« but also of biblical interpretation. Namely, we can expect that Jesus lived, thought, spoke, and taught as a Jew and not as a »Christian« in the historical sense of the word.

Based on this reasoning, in the first part of the paper, we will address certain theological and historical reasons for the exclusion of the Jewishness of Jesus from both Judaism and Christianity. In the second part, we will discuss the importance of the Jewishness of Jesus for understanding the worldview context of the biblical authors. In the last part, as a case study, we will demonstrate through the interpretation of Matthew 16,13-20 (the issue of "the rock") and Luke 11,1-4 (the Lord's Prayer) through "Jewish eyes " that we can gain a different and even better interpretation of these two texts that better fit the context of the biblical writers.

\section{The Jewishness of Jesus: Judaism and Christianity}

Jesus was a Jew, but was his religion Judaism or Christianity? In addressing this question, we have to realize that being a "Jew « does not imply the acceptance of any branch of Judaism, because one can be a Jew and not religious. The question of Jesus' Jewishness is actually aimed at the question of his religion. Namely, did Jesus come to establish a new religion or did he come to fulfill, by Paul's words, "what was promised to the 


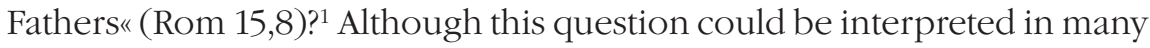
ways and has many significant consequences, my focus will be on hermeneutics - notably the Gospels. Let us first explore the Christian and then the Jewish view of the Jewishness of Jesus.

\subsection{Christianity}

According to Garber and Hanson (2020, vii), »over the centuries, the historical Jesus has effectively been 'de-Judaized' to such an extent that pointing out the obvious has in fact become germane. For most modern people it is all but impossible to pull back the curtain of what became Catholic, Greek Orthodox and Protestant Christianity to appreciate the Jew who preceded the faith established in his name." Markus Barth $(2015,11)$ also said that " $[\mathrm{m}]$ any people today apparently find it possible to separate the memory of the Jew Jesus from the belief in Jesus Christ. To state that Jesus is a Jew is to insult, distress, annoy, and, indeed, provoke them to the point of contradiction, suspicion, and hatred."

Géza Vermès $(2003,53)$ identifies the origin of this attitude in the conflicts recorded in the New Testament. First, the Gospels demonstrate conflict between Jesus and some of his fellow countrymen. Second, we have a conflict between the apostles and the Palestinian Jews, which has continued from the first century AD onward. These conflicts portrayed Jesus as an opponent to Judaism and therefore the Gentile church grew in this attitude, viewing Judaism as being hostile to Christianity. So much so, that according to Vermès $(2003,54)$ "any recognition of Judaism as not being totally alien to Christianity would have appeared to most church fathers as gross disloyalty to their faith." The conflict of Jesus with Judaism gave birth to a new religion - Christianity.

Luckily, we live in a time when Jesus as a Jew is for the most part not a questionable topic. According to Tom Holmén $(2007,2)$ in his critique of »The Quest of the Historical Jesus«, Albert Schweitzer had stressed, in opposition to the liberal and modernized Jesus, the Jewish background of Jesus

1 Even though she is not discussing the issue of Christianity vs. Judaism, in the article Od poetizacije poslanstva $v$ Stari zavezi do polnosti misijona $v$ Novi zavezi, Irena Avsenik Nabergoj discusses in a profound way the missionary role of Israel in reaching the Gentiles $(2018,693)$. 
and the necessity of understanding Jesus within the Judaism of his time. William E. Phipps $(1993,9)$ also pointed out that among scholars devoted to the historical origin of Christianity, the Jewishness of Jesus was no longer a matter of debate. As E. P. Sanders asserted, there is now a virtually unanimous consent that Jesus lived as a Jew. Sanders also argued that we must read the New Testament as a source for first-century Judaism (Phipps 1993, 9). Accordingly, the current »Third Quest« acknowledges Jesus' Jewishness and maintains that a plausible picture of the historical Jesus should be at home within first-century Palestinian Judaism. Based on this, Holmén $(2007,3)$ observes that this final quest resulted in the idea of Jesus as a Jew being no longer marginal but becoming a mainstream attempt to understand Jesus in a continuum with the Judaism of his time rather than in contrast with it. Matthias Henze (2018, 15-16) is also in agreement with this when he says that some Christian scholars in the last 100-150 years developed a different yet negative outlook on Judaism. For some, Judaism had lost its relevance and its legitimacy with the appearance of Jesus and his followers. Others went even further by claiming that Israel was no longer God's chosen nation and that it had been replaced by the Church. However, in the last half century, some very significant changes have occurred in how scholars approach and view the Jewish world of the New Testament, and for Henze that means taking into consideration the literature that was produced in the Second Temple period and reading the New Testament as part of the much larger world of ancient Judaism.

If we agree with Holmén $(2007,3)$ that Jesus was a part of the diverse and heterogeneous Jewish religiosity also called early »Judaisms", Garger and Hanson (2020, viii) rightly point out the issue of the Jewishness of Jesus:

To be sure, identifying Jesus as a Jew is hardly sufficient given the multitude of ancient sects inhabiting the land of Israel during the Second Temple period. We know a great deal about Pharisees, Sadducees, Essenes, et al., and entire treaties have identified Jesus with the Zealot camp. Creating a compelling »ID « for Jesus is an understandably complex daunting and even mystifying task, since virtually every letter of every word of the texts we have about him has been and remains subject to vigorous debates and skeptical criticism. 


\subsection{Judaism}

To present a Jewish view on the Jewishness of Jesus is a difficult task. In the Talmudic collection of teachings, Jesus is described as a bastard and sorcerer. Leonard Swidler $(1988,2)$ puts both Christians and Jews in the same boat« when he writes that the Jewishness of Jesus is ignored by both sides:

Both Christians and Jews automatically think of Jesus as the name of someone other than a Jew. This simple fact tends to cut Christians off from the taproot of their religion, the Hebrew-Jewish tradition. On the other side it also tends to cut Jews off from a very important son of their tradition, one who has become the most influential Jew of all history surpassing in historical impact even such giants as Moses, David, Marx, Freud and Einstein.

According to Peter Zaas $(2001,15)$ the question "Who is Jesus" is not a question that has been of great concern to Jews throughout their history. He also claims that "there is no Jewish position on who Jesus was«, so the question of Jesus' precise historical identity bears very little weight among the range of Jewish religious concerns. ${ }^{2}$ His argument is based on the fact that Judaism is non creedal, it is not based on a set of beliefs that all Jews share, and it does not have one central authoritative structure to determine what Jews should or should not believe about this or any other issue.

Phipps $(1993,10)$ states that certain eminent Jewish scholars in the past concluded that Jesus was a Pharisee, e.g. Abraham Geiger called Jesus a Galilean Pharisee. Further, Joseph Klausner, who was an Orthodox Jew, attempted to prove that Jesus remained a true Pharisaic Jew. Martin Buber also stated that the death of Jesus occupied a position within this circle of belief. Also, some contemporary Jews associate Jesus with the Pharisees, such as Hebrew Union College professor Ellis Rivkin and Rabbi Harvey Falk. Phipps (10-11) recognizes that the idea that Jesus might have been

2 Responding to Zass' claim about the lack of the Jewish position on Jesus, Donald A. Hagner (2001, 45) says that strictly speaking, this is true, since there is no official Jewish estimate concerning the person of Jesus, who he was and his significance. But, among Jews there is clearly agreement on who he was not. 
a Pharisee is difficult to swallow because Jesus in the gospels harshly rebuked the Pharisees. Therefore, Jesus as a Pharisee is an oxymoron.

Observing the North American context, Shaul Magid $(2013,133)$ writes:

Contemporary Jews in America do not seem very interested in Jesus. Few rabbis today sermonize about Jesus from the pulpit and there are few courses about Jesus (or Christianity) in formal or informal Jewish education. Contemporary scholar of the New Testament Amy-Jill Levine correctly notes in passing, „If on the popular level we Jews are willing not only to acknowledge but also to take pride in the Jewishness of such generally non-observant Jews as Sigmund Freud, Albert Einstein, the Marxes (Karl and Groucho although Karl was baptized as a child), and Jerry Seinfeld, why not acknowledge the quite observant Jesus? [...] I have heard rabbis in Reform and Conservative synagogues cite Homer (both the Greek poet and Bart's father), Plato, the Buddha, Muhammad, Gandhi, Martin Luther King Jr., the Dalai Llama, and even Madonna (the Kabbalah-besotted singer, not the mother of Jesus). At least Jesus is Jewish with regard to family, practice, and belief."

Based on the variety of responses, what can we conclude about the Jewish stance toward Jesus as a Jew? Even though responses can vary from hostility to ignorance, it is safe to say that the question of Jesus' Jewishness on a historical level is not problematic for nowadays Jews. According to Shaul Magid (135), »Jews are generally more comfortable with a historical Jesus because it allows them to circumvent the doctrinal problems of Christology and treat Jesus as a 'Jew'." So, we can conclude that talking about Jesus as a Jew becomes more of an issue when we discuss the Jewishness of his teachings, his messianic claims and especially Christology, which implies Christian beliefs regarding Jesus' divinity.

\subsection{Jesus - a Jew or a Christian?}

Today and for the last 2000 years, we have on the one hand Christianity that celebrates Jesus as the Jewish messiah, incarnated by God, who is more or less devoid from his Jewishness, and on the other hand, we have 
Judaism where Jesus is viewed as the founder of a new religion distinct from Judaism.

Analyzing the Jewish-Christian relationship goes beyond the scope of this article, but if we take Craig A. Evans' (2014, 143-44) best-selling author Craig A. Evans looks at how a tumultuous chain of events from 30-70 CE--beginning with Jesus's entry into Jerusalem and subsequent crucifixion and ending with the destruction of the temple-led to the separation between the followers of Jesus and other Jews. Topics include the following: 1 discussion about the root causes of the Jewish-Christian rift, we can name several factors that have caused or contributed to this rift. First, Christianity's aggressive Gentile mission and lenient requirements for entry into the Church was out of step with Jewish proselytism where Jewish proselytes were instructed to take on the yoke of the Torah (m. Abot 3:5), which involved scrupulous observation of Sabbath and food laws. Second, the divinization of Jesus made Christianity all the more unacceptable to Jews because it appeared as a direct violation of the first commandment. Third, the ethnic shift that manifested in the decline of Jewish membership in the early Church and an increase in Gentile membership began to erase the Jewish character of the Church, which in turn discouraged the entry of Jewish converts. One consequence of such a shift was that the Septuagint became the preferred version of the Scriptures of the early Church rather than the Hebrew Old Testament and its Aramaic interpretation. For Evans, this preference of the Septuagint drove Gentile and Jewish believers further apart. Fourth, Jewish nationalistic interests eventually led to the destruction of Jerusalem and the Herodian Temple in 70 CE and later the Bar Kokhba defeat (135), resulting in the loss of Jerusalem as a Jewish city and of Israel as a state, which signified the loss of common ground shared by Gentile and Jewish Christians and led to the persecution of Christians by Bar Kokhba. Evans further argues that the Jewish wars for liberation from Roman control and the hopes for rebuilding the temple were especially difficult for Jewish Christians because they were often forced to choose between their faith in Jesus and their loyalty to their nation and people. But the fundamental factor of the Jewish-Christian rift was that »for many Jewish people were the simple facts that Jesus had been put to death and the kingdom of God had failed to materialize. Both of these points apparently nullified any messianic claim.« $(2014,145)$ In other words, Jesus failed to establish the kingdom of God on earth, 
and he did not reign as Israel's king since Israel remained under Roman subjugation.

As noted before, discussing the Jewishness of Jesus opens some difficult questions in the relationship between Judaism and Christianity, however, our goal here is to see how Jesus' Jewishness should affect Christian hermeneutics. Granted, different Christian traditions read and interpret the Bible differently and have different standards that give authority to their interpretation. Hence, on one hand it is pointless to argue that something is valid and normative for all Christians. On the other hand, if we claim that we follow a Jewish Messiah, then our hermeneutics has to take into serious consideration his Jewishness. Marvin Wilson $(1989,167)$ is on track when he says: "Westerners have often found themselves in the confusing situation of trying to understand a Jewish Book through the eyes of Greek culture. $\mathbb{1}^{3}$ Hermeneutics is not only a matter of method/s but is also a theological outlook or assumption. Therefore, the words of Abraham Joshua Heschel $(1990,302)$ should be well noted:

The process of dejudaization within the church paved the way for abandonment of origins and alienation from the core of its message. The vital issue for the Church is to decide whether to look for roots in Judaism and consider itself an extension of Judaism, or to look for roots in pagan Hellenism and consider itself as an antithesis to Judaism. The spiritual alienation from Israel is most forcefully expressed in the teaching of Marcion, who affirmed the contrariety and abrupt discontinuity between the God of the Hebrew Bible and the God whom Jesus had come to reveal.

3 Jaroslav Pelikan (1997, 21-22) in his book Isus kroz stoljeća [orig. Jesus Through the Centuries] says that for the first-century Christians the image of Jesus as a rabbi was self-evident, for second-century Christian scholars it was embarrassing, and for third-century Christian scholars and later it was unknown. Pelikan further explains that as the Christian movement spread more and more among the Gentiles, it had become less and less Jewish in terms of membership and outlook. In such a setting, Jewish elements from Jesus' life became increasingly problematic, and it had to be explained to the Gentile readers of the gospels. 


\section{The importance of the Jewishness of Jesus for understanding a worldview context of the biblical authors}

Jesus was a Jew, but it is debatable what kind of a Jew he was. As a Jew, his faith was Judaism, and that should have huge hermeneutical implications for Christians today. First, Jesus' Bible was what Christians call the Old Testament or Tanakh. His teachings were filled with quotations from the Tanakh; but there is more. Since Jesus lived in a biblically literate culture that was well acquainted with biblical texts, he (as well as all rabbis) used the technique of allusion to communicate his message. This way of communication requires that the hearers are well-versed in the biblical text or the allusion will not make sense to them. The Rabbinic allusion is a technique where the speaker cites one part of the verse and the rest remains unspoken. The hearer needs to supplement what is unspoken based on his or her knowledge of the biblical text. Sometimes a reference can only be one or two words, making it more important what Jesus did not say rather than what he said.

Second, the basis for his teaching was the Tanakh, but as Matthias Henze $(2018,12)$ notices, "the religion of the Old Testament is not the Judaism of Jesus«. Henze refers to the fact that Jesus taught in synagogues, that his disciples called him rabbi, that he was involved in conversations with the Pharisees and that he expelled demons; and none of this is mentioned in the Tanakh. So, if we want to hear Jesus' teaching, our priority should be deep knowledge of the Tanakh as well as acquaintance with the Second Temple period, its literature and development of ideas in Judaism.

Third, if Jesus was a Jew, this means that he thought as a Jew, taught as a Jew, lived as a Jew, worshiped as a Jew, etc. Yes, Jesus' Bible was the Tanakh, but the way he interpreted it was with a Jewish mindset or worldview. Summarizing the issue of biblical interpretation, Michael Heiser (2019) notices that Christian history and Christian thought was not the context of the biblical writers, and so it cannot be the correct context for interpreting what they wrote. The same goes for the church fathers who lived one thousand years or more after most of the Old Testament was written, and less than a half dozen of them could read Hebrew. In terms of the New Testament, the period was a century or more away from important early theologians like Tertullian and Irenaeus and some of them, 
such as Augustine, lived three hundred years after the conversion of Paul. Heiser (2019) continues by saying that the context for interpreting a biblical text is not the Catholic Church, the rabbinic movements of late antiquity and the Middle Ages, the Reformation (Luther, Calvin, Zwingli, the Anabaptists), the Puritans or evangelicalism in any of its flavors. His answer is the following:

So what is the proper context for interpreting the Bible? Here's the transparently obvious truth I was talking about: The proper context for interpreting the Bible is the context of the biblical writers - the context that produced the Bible. Every other context is alien or at least secondary.

Heiser aims at the fact that we all read the Bible through certain filters (our time, culture, history of our church tradition, etc.) which, if we are not careful, can be misleading in our reading of the Bible. Since his teachings are obligatory for Christians, we are obligated to know and live these teachings. But how can we do this if we ignore the Jewishness of Jesus and/or replace it with a different context and foundation? Heiser (2015, EPUB location 14) concludes:

The biblical text was produced by men who lived in the ancient Near East and Mediterranean between the second millennium $\mathrm{BC}$ and the first century AD. To understand how biblical writers thought, we need to tap into the intellectual output of that world. [...] As our understanding of the worldview of the biblical writers grows, so does our understanding of what they intended to say - and the mosaic of their thinking takes shape in our minds.

If we take Jesus' Jewishness seriously in the field of hermeneutics, we should pay attention to what Heiser is saying. Yes, we should know the Old Testament and we should be familiar with the literature of the Second Temple period, but we should also be diligent in reading the Bible through the eyes of biblical writers. And in order to be successful in doing so, we need to discover their worldview. Our goal should therefore be studying the historical, cultural or literary context in order to discover a worldview context of the biblical authors and then adopt a new approach to the reading of the Scriptures with our new »glasses«. Ray Vander Laan points 
us in the right direction when he says that most of the inspired human authors of the Bible, as well as those to whom the words were originally given, where Jews living in the ancient Near East. Due to this fact, their writings clearly bear the stamp of time and place. Even though the message of the Bible is eternal and unchanging, it was conveyed within the circumstances and conditions of the people of the Bible, and the message is unique to their times. Hence, "we most clearly understand God's truth when we know the cultural context within which he spoke and acted and the perception of the people with whom he communicated « $(2009,7)$. Laan observes that this fact does not mean that God's revelation is unclear if we don't know the cultural context, but »by learning how to think and approach life as Abraham, Moses, Ruth, Esther, and Paul did, modern Christians will deepen their appreciation of God's word. To fully apply the message of the Bible to our lives, we must enter the world of the Bible and familiarize ourselves with its culture.«(7)

\section{Practical examples: interpreting Matthew 16,13-20 (the issue of "the rock") and Luke 11,1-4 (the Lord's Prayer) through »Jewish eyes"}

In order to demonstrate how the worldview context affects our reading of the Bible, I will offer two practical examples where Catholics and Evangelicals differ in interpretation.

\subsection{The Lord's Prayer}

What is the proper way of praying the Lord's Prayer? Alexander A. Sosheel (2010,24) notices that even though Christians generally believe that the Lord's Prayer is the Word of God and a very important part of the Christian faith, »[s]ome Christians pray this in a routine on daily basis or in every worship meeting. The Catholic Church teaches to repeat this more than once. They repeat this prayer in meditation or in church services. Some Christians believe this prayer is a pattern prayer to teach us how to pray and what to pray [sic]." In her article about the Lord's Prayer, Agnes Cunningham $(1999,692)$ begins by saying: »Model prayer taught by Jesus to his disciples (Matt. 6,9-13; Luke 11,2-4).« Later she says: „From earlier times, Christians have looked on this prayer as a model, taught by Jesus 
as a form or pattern of how his disciples were to pray and what requests they were to address to the heavenly Father."What Cunningham gives is an exceptionally good summary of the common Evangelical view of the Lord's Prayer, explaining why Evangelicals usually do not pray this prayer by repetition. More precisely, when Christians in liturgical churches repeat the words of the prayer, Evangelicals usually connect this with Jesus' words about vain repetitions in Matthew 6,7 (NIV): »And when you pray, do not keep on babbling like pagans, for they think they will be heard because of their many words."

But if we look at this prayer through a Jewish context, we get some additional insights. Ann Spangler and Lois Tverberg (2009, 82-83) observe that the Lord's Prayer could be a summary of the Amidah because it encompasses several of its themes and because other rabbis of Jesus' time taught summary versions of the Amidah in order to illustrate what prayer should be like at its essence. They also pointed out that the early Church prayed the Lord's Prayer three times each day, just as the Amidah was prayed.

Kenneth Bailey $(2008,94)$ notices points of similarity and differences between the Amidah and the Lord's Prayer. Regarding similarities, Bailey writes: »For example, a request for daily bread occurs at about the same place in the middle of both the Tefillah and the Lord's Prayer. Some introductory phrases are similar. Both prayers talk about the needs of the present and both mention the coming kingdom of God. Some of the same rhymes and rhythms appear in each. The doxologies of the two overlap. Finally, both are intended for individual as well as community use." Regarding dissimilarities, Bailey (107) says that the Amidah is clearly a prayer for a particular ethnic community centered in Jerusalem. However, Jesus dezionizes the tradition because the Lord's Prayer contains no reference to Jerusalem or the temple. Instead, Jesus teaches his disciples to pray for the kingdom of God to come »on earth", which according to Bailey, reflects a global concern for all people. Also, forgiveness is tied to forgiving others; no attack on outsiders is voiced. Jesus' prayer does not contain a request for God to look on the suffering of his people or for God to fight for them.

The Babylonian Talmud in the tractate Berakhot 16b-17a contains examples of personal prayers that rabbis would say after finishing the corporate 
prayer the Amidah. Presumably, the talmidim of these rabbis would also pray these prayers, which would identify them as followers of that particular rabbi. Now, why is that significant? Because a similar mindset could have been present behind the request »teach us to pray« in Luke. Namely, Luke 11,1 says: »One day Jesus was praying in a certain place. When he finished, one of his disciples said to him, 'Lord, teach us to pray, just as John taught his disciples.' (Luke 11,1 NIV) The details of this text are important. First, Jesus was presumably praying alone. Second, one of the disciple approaches Jesus asking him »teach us to pray«. What did this disciple ask Jesus? What is the idea behind this request? Did Jesus' disciples, who were Jews, need a course or seminar »Intro to Prayer « because they did not know what and how to pray? Or were they maybe asking something else? That leads us to the third detail of the text, which is key for understanding this request: »just as John taught his disciples."Both John and Jesus were rabbis, and in both instances we see that the duty of a rabbi was to teach his disciples to pray. Since it is unlikely that both John's and Jesus' disciples did not know how to pray at all, it is more likely that Jesus' disciple asked Jesus on the behalf of the group to give them one prayer that would identify them as the talmidim of Jesus. If this is the case, then the Lord's Prayer is a prayer that actually should be prayed by repetition and is not a model or pattern of prayer.

\subsection{The »Rock»}

Another example where Christians differ in interpretation is the issue of "this rock" from Matthew 16,18: "And I tell you that you are Peter, and on this rock I will build my church, and the gates of Hades will not overcome it." When Jesus says "and on this rock", who or what is he talking about? In short, and simplified, to the Catholic Church Jesus' words meant that Peter was the rock upon whom the Church would be built, while for Protestants and Evangelicals »this rock « represents either Jesus himself or Peter's confession of faith. Steve King $(2019,54)$ observes that these Jesus' words can be interpreted in three different ways: two we already mentioned, and the third option is that Jesus is saying that his church will be built upon this »bedrock of paganism« in front of which they were standing. I would argue that if we take historical context and geographical location into consideration, first two interpretations are incorrect. Hence, 
let us observe argumentations that support the third interpretation, and as the representative of this view, we will take Michael Heiser.

First, the geographical setting is important for the understanding of this text. The event from Matthew 16 occurs at Caesarea Philippi. The city of Caesarea Philippi/Banias is located at the foot of Mount Hermon, and both locations are part of a wider area called Bashan. In the Bible, Bashan is first mentioned in connection with king Og (Num 21,33; Deut 3,1). In Joshua 12,4-5, Og is defined as one of the Rephaims who also reigned in Ashtaroth and Edrei. Heiser (2015, EPUB location 205) points out that Ashtaroth, Edrei, and the Rephaim are mentioned by name in Ugaritic texts where the Rephaims of Ugarit are described as quasi-divine dead warrior kings who inhabit the underworld. Furthermore, in the Ugaritic language, the location of Bashan was pronounced and spelled Bathan, and for Heiser "[t]he linguistic note is intriguing since Bashan/Bathan both also mean 'serpent', so that the region of Bashan was 'the place of the serpent' ${ }^{4}{ }^{4}$

Mount Hermon is also significant because according to 1 Enoch 6,1-6, this was the place where the sons of God of Genesis 6 descended when they came to earth to have intercourse with human women, and the result of such relationships was the race of giants called Nephilim. ${ }^{5}$ In Hebrew, Hermon is pronounced khermon, and the noun has the same root as the verb kharam, "to devote to destruction." Accordingly, »[t]his is the distinct

4 Based on this, Heiser furthermore makes a connection between the serpent from Genesis 3, the rebellion in celestial and human family, etc. Also, referring to Psalm 68, Heiser (2015, EPUB location 290) makes the following comparison between Sinai and Bashan: "The first thing that sticks out in this passage is that the infamous Mount Bashan is called the 'mountain of God' $(68,15)$. The phrase 'mountain of God' is actually 'mountain of elohim' (har elohim) in Hebrew. That means it can be translated as either 'mountain of God' or 'mountain of the gods'. The latter makes more sense than the former for the very obvious reason that the two mountains in the passage - Bashan and Sinai are rivals at the beginning of the psalm. The mountain of the gods (Bashan) 'looks with hatred' at Yahweh's mountain, Mount Sinai. God desired Sinai for his abode, and the psalmist asks Bashan, 'Why the envy?' This would make little sense if Bashan had already been under Yahweh's authority."

5 "6,1 And it came to pass when the children of men had multiplied that in those days were born unto them beautiful and comely daughters. 2 And the angels, the children of the heaven, saw and lusted after them, and said to one another: 'Come, let us choose us wives from among the children of men and beget us children.' 3 And Semjâzâ, who was their leader, said unto them: 'I fear ye will not indeed agree to do this deed, and I alone shall have to pay the penalty of a great sin.' 4 And they all answered him and said: 'Let us all swear an oath, and all bind ourselves by mutual imprecations not to abandon this plan but to do this thing.' 5 Then sware they all together and bound themselves by mutual imprecations upon it. 6 And they were in all two hundred; who descended in the days of Jared on the summit of Mount Hermon, and they called it Mount Hermon, because they had sworn and bound themselves by mutual imprecations upon it."(Charles 2006, 11-12)

Edinost in dialog 76 (2021) 1: 43-62 
verb of holy war, the verb of extermination. It has deep theological meaning, a meaning explicitly connected to the giant clans God commanded Joshua and his armies to eradicate.« (Heiser, EPUB location 205) ${ }^{6}$

Second, a pagan history of the city of Caesarea Philippi must be taken into the consideration. Caesarea Philippi was originally established by Alexander the Great. After his death, Ptolemies ruled this area and introduced worship of the god Pan. And this place of worship was very close to the Israeli sanctuary of Dan. Božo Lujić (2016, 395-99) notices that Hellenists were probably aiming to erase the worship of YHWH as the God of Israel. The name Paneas, according to the name of the Greek god Pan, was changed because in the Arabic language the letter " $\mathrm{p}$ « is transferred into »b«, so the city was also called Banias. A shrine to the Greek god Pan was located near a stiff rock, and beneath it there was a cave or grotto that was considered bottomless. This cave was called the Gates of Hell and the water that sprung from this cave came from Mount Hermon and represented one of the three sources for the river Jordan. Additionally, since the Roman emperor Augustus gave this city and the surrounding countries to Herod the Great as a token of gratitude, Herod built a temple nearby dedicated to Augustus. Due to wars and tectonic movements of the ground, the city and the temple were not preserved. However, in the rock from which the water flowed beneath, there are still niches where statues of gods were located (Pan, his father Hermes and goddess Nemesis). Remnants of inscriptions testify that this location was quite significant in the past.

If we read the event from Matthew 16, taking into consideration geographical and historical context, we can propose a third reading or interpretation of the expression "rock" that makes most sense in the biblical context. Namely, when Jesus said these words, he was standing in front of or somewhere near the massive rock with niches of various gods beneath, where the grotto called "gates of hell« is located. These "gates« served as the gates where fertility gods went during winter and returned in the spring to give life to the earth (the symbolism of water as the source of life is crucial

6 Before the worship of Pan was introduced, the Phoenicians who worshipped the Baal (Jezebel, 1 Kgs. 18,19) considered Mount Hermon to be the mountain of Baal. In the Bible, Mount Hermon was also known as Mount Baal-Hermon (Judg. 3,3; 1 Chron. 5,23). 
as well). Given all these factors, we can say that Jesus went into the center of pagan worship to declare his identity and announce his upcoming victory. Accordingly, »this rock « is the rock which symbolizes pagan worship and all spiritual influences behind it. Therefore, the mentioning of sthe gates of hell« makes sense only if these "gates« relate to this »rock« and vice versa. Based on this, Heiser (2018) concludes the following:

The rock which Jesus referred to in this passage was neither Peter nor Himself; it was the rock on which they were standing - the foot of Mount Hermon, the demonic headquarters of the Old Testament and the Greek world. We often presume that the phrase »the gates of hell shall not prevail against it« describes a Church taking on the onslaught of evil. But the word "against« is not present in the Greek. Translating the phrase without it gives it a completely different connotation: »the gates of hell will not withstand it.« It is the Church that Jesus sees as the aggressor. He was declaring war on evil and death. Jesus would build His Church atop the gates of hell - He would bury them.

Similarly to Heiser, King $(2019,54)$ says that it is fascinating to place Jesus' promise that "gates of hell« will not overpower the church in the context of the setting were Jesus was - in front of the spring by that name. And if we take into the consideration the fact that "gates « have a defensive, not an offensive purpose, we might conclude that Jesus was not only talking about the mere physical eradication of pagan worship, but also about concrete victory over spiritual forces that drove and stimulated such worship. The fact that Jesus starts talking about his death from v. 21 supports the idea that the defeat of spiritual forces (destruction of the power of hell) will happen because of his sacrificial death.

According to this interpretation, Jesus declared that his Church would replace pagan places of worship such as Caesarea Philippi, and he used objects, people and/or situations he was surrounded by in his lectures, as Jewish rabbis often did. Hence, »the rock« in this verse is not Peter, Jesus or his confession of faith. I therefore suggest that support for the claim that Peter was the first pope (Catholic position) or that Jesus was the rock 
upon which the Church was built (Protestant position) should be sought in other biblical verses.?

\section{Conclusion}

The purpose of this article was to point out the importance of Jesus' Jewishness for reading and interpreting the Bible. This should not only drive us to understand the Old Testament and become acquainted with the literature from the Second Temple period, but it should also help us realize that by studying various contexts (historical, cultural, biblical, etc.) we can discover the worldview of the biblical writers in order to better understand their writings.

In the two examples that were offered in this article, we saw that by taking into consideration the Jewishness of Jesus, we can shed new/old light on familiar passages that have acquired different interpretations through the course of time. These, in Heiser words, are probably the result of »filters", as they are in fact contrary to the context that produced the Bible. The example of the Lord's Prayer is not that problematic because whether someone prays this prayer through repetition or uses it as a template does not significantly impact their walk with God. The second example could cause some disagreement because Matthew 16 is the text that the Catholic Church uses as support for the claim that Peter was the first pope. However, I opposed the Catholic, Protestant and Evangelical interpretations of this text, suggesting that support for their claims should be sought in other places in the Bible.

$7 \quad$ Ray Vander Laan $(2008,33)$ recognizes the fact that throughout church history there have been discussions and debates on what exactly Jesus meant when he said these words. Laan also claims that the setting where Jesus was "the rock " refers to "the rock of pagan values and dead idolatry that was so prominent in Caesarea Philippi«. In addition, if Jesus wanted to declare that somehow Peter was "the rock " upon which the church would be built, he could do this elsewhere. But in this context, if Jesus really means that Peter is the rock, that means that "the pagan rock « in front of which they all stand remains intact because while this rock represents paganism, Jesus will use another rock to build his community of worshipers, and not that "one rock « will replace »the other". The fact that in v. 19 Jesus gives keys to Peter does not influence "rock« imagery. According to Walton and Keener (2019, 1659), palace keys were large, and an important official carried them. So, when Jesus gives Peter the power "to bind and to loose«, this may include disciplinary authority (cf. Mt 18,18) but also authority to evaluate those to be admitted (cf. an officer with a similar function at Qumran). The basis for true admission, according to them, is the shared confession of v. 16. 
The quest for Jesus' Jewishness in biblical studies is more and more prominent, and I consider this a positive shift. This does not mean that Christian traditions have misinterpreted everything, but such a shift requires a willingness to revise our doctrine and practices in some cases, and in others to delve deeper than we had before. Even though the quest for Jesus' Jewishness in some Evangelical circles could result in Gentile believers in Christ striving to live "as Jews «, I believe that the New Testament clearly teaches that Gentile believers are grafted to Israel, but not that they must become Jews. Likewise, in the context of Jewish believers in Christ, they should not be forced or urged to become and live "as Gentiles«. I am ending this article with a quotation from Young $(2007,216-17)$ who, in my opinion, nicely summarizes its topic:

Jesus brought Judaism to the world. The content of the Sermon on the Mount is intimately connected to the concepts of the old Judaism practiced by the Jewish people during the days of the Second Temple period. Jesus instructs his followers to make disciples and to teach commandments. His interpretation of the Torah and the commandments show his followers how to live a life of purposeful obedience through a deeply spiritual walk and inner life.

How ironic it is, then, that the world has invented its own brand of Christianity. Some Christians want Christianity to be distinctively different from any vestige of the old Judaism. Their brand of faith and belief often is devoid of commandments and good works. They build a wall of separation between the Christianity that Jesus revealed in the Sermon on the Mount and the Judaism lived by Jewish people in daily life. They neglect the fact that Jesus was a Jew. Contrary to popular opinion, Jesus never converted to Christianity. He provided an example to all by living the Jewish faith in daily life. [...] True Christianity that honors the life and teachings of Jesus must be rooted in the best of true Judaism. 


\section{References}

Avsenik Nabergoj, Irena. 2018. Od poetizacije poslanstva $v$ Stari zavezi do polnosti misijona v Novi zavezi. Bogoslouni vestnik 78/3: 679-694.

Bailey, Kenneth E. 2008. Jesus Through Middle Eastern Eyes: Cultural Studies in the Gospels. Downers Grove: IVP Academic.

Barth, Markus. 2015. Jesus the Jew: What Does It Mean That Jesus Is a Jew? Eugene: Wipf and Stock.

Charles, R. H., ed. 2006. The Book of Enoch. San Diego: Book Tree.

Cunningham, Agnes. 1999. Lord's Prayer. In: Everett Ferguson, ed. Encyclopedia of Early Christianity: Second Edition, 692. New York: Routledge.

Evans, Craig A. 2014. From Jesus to the Church: The First Christian Generation. Louisville: Westminster John Knox Press.

Garber, Zev, and Kenneth Hanson. 2020. Judaism and Jesus. $1^{\text {st }}$ edition. Newcastle upon Tyne: Cambridge Scholars Publishing.

Hagner, Donald A. 2001. Jesus: Bringer of Salvation to Jew and Gentile Alike. In: Paul Copan and Craig A. Evans, eds. Who Was Jesus? A Jewish-Christian Dialogue, $1^{\text {st }}$ edition, 45-58. Louisville: Westminster John Knox Press.

Heiser, Michael S. 2015. The Unseen Realm: Recovering the Supernatural Worldview of the Bible. First Edition Used edition. Bellingham: Lexham Press.

- - -. 2018. What Did Jesus Mean by »Gates of Hell«? The Logos Bible Software Blog. Https://blog.logos.com/2018/04/ jesus-mean-gates-hell/.

- - - 2019. What Is the Proper Context for Interpreting the Bible?. LogosTalk (blog). Https://blog.logos.com/2019/05/what-is-the-proper-context-for-interpreting-the-bible/.

Henze, Matthias. 2018. Isusova Čitanka: Izvanbiblijski spisi pomažu razumjeti Isusa. Zagreb: KruZak.
Holmén, Tom. 2007. An Introduction to the Continuum Approach. In: Tom Holmén, ed. Jesus from Judaism to Christianity: Continuum Approaches to the Historical Jesus, 1-16. New York and London: T\&T Clark.

Heschel, Abraham Joshua. 1990. Protestant Renewal: A Jewish View. In: F. Rothschild, ed.Jewish Perspective on Christianizy, 302. New York: Crossroad.

King, Steve. 2019. The Slow Lakes: Eight Ways Ministry Leaders Can Thrive and Finish Strong. New Jersey: Salem Books.

Laan, Ray Vander. 2008. Early Church: Becoming a Light in the Darkness. Grand Rapids: Zondervan.

- - -. 2009. Life and Ministry of the Messiah. Grand Rapids: Zondervan.

Lujić, Božo. 2016. Tragovima Biblijskih Prostora i Događaja. Zagreb: Kršćanska sadašnjost.

Magid, Shaul. 2013. American Post-Judaism: Identity and Renewal in a Postethnic Society. $2^{\text {nd }}$ edition. Bloomington: Indiana University Press.

Pelikan, Jaroslav. 1997. Isus Kroz Stoljeća. Mostar: Ziral.

Phipps, William E. 1993. The Wisdom and Wit of Rabbi Jesus. Louisville: Westminster John Knox Press.

Sosheel, Alexander A. 2010. Understanding the Will of God. Littleton: Xulon Press.

Spangler, Ann, and Lois Tverberg. 2009. Sitting at the Feet of Rabbi Jesus. Grand Rapids: Zondervan.

Swidler, Leonard J. 1988. Yeshua: A Model for Moderns. Kansas City: Sheed \& Ward.

Vermès, Géza. 2003. Jesus in His Jewish Context. London: SCM Press.

Walton, John H., and Craig S. Keener. 2019. Cultural Backgrounds Study Bible. Grand Rapids: Zondervan.

Young, Brad H. 2007. Meet the Rabbis: Rabbinic Thought and the Teachings of Jesus. Grand Rapids: Baker Academic. 
- - -. 2012. The Parables: Jewish Tradition and Christian Interpretation. Grand Rapids: Baker Academic.
Zaas, Peter. 2001. Who Was Jesus? A Jewish Response. In: Paul Copan and Craig A. Evans, eds. Who Was Jesus? A JewishChristian Dialogue, $1^{\text {st }}$ edition, 15-20. Louisville: Westminster John Knox Press. 